\title{
The Strategy of Lithuanian State Security in the 21st Century
}

\author{
Robertas Pukenis \\ Doctor of Church and Civil Law, Dctor of Italian Civil Law and Lic. of \\ Theology; docent at the Department of Public Administration at the Faculty \\ of Political Science and Diplomacy of Vytautas Magnus University, \\ Lithuania
}

doi: 10.19044/esj.2017.v13n19p15 URL:http://dx.doi.org/10.19044/esj.2017.v13n19p15

\section{Abstract}

The article analyses state security as harmonious functioning of the constitutional system without interference of any outside forces, protection of territorial integrity and undisturbed functioning of a state in all public spheres. The state security in the broadest sense is strengthened by the factors of foreign and home policy. The security is based not only on strong, well trained armed forces, equipped with modern guns but also on the entire potential of a state: the approval of citizens for armament and the willingness to defend the country; economic stability, functioning of democratic principles, positive contribution of national communities into the welfare of the society, harmonious agreement of national communities, loyalty to the Constitution of the Republic of Lithuania and the competence of the Department of State Security to neutralise the forces willing to harm the consolidation of the State; they penetrate into the governmental institutions, instigate slanderous moods against the leaders or institutions of the state via mass media. The history reminds us that the West often used to betray nations; thus the question may arise whether the NATO will succeed in defending the Baltic countries according to the binding provision of Article 5 that obligates the parties for collective defence. Therefore, Lithuania urgently needs an augmented distribution of NATO toops in the Baltics. Further strategy requires insightful diplomatic steps in oreder to preserve peace and establish friendly alliances, e. g. a stronger military cooperation with Scandinavian states, brotherhood with Latvians and Estonians and approval of the dispositions of the Polish President to create a union "from the sea to the sea". Conclusive thoughts are based on the arguments of serious political observers, sociological research, official statistics and verified data. The aim of this article is to describe the strategy of Lithuanian Republic in the field of security in the beginning of the $21^{\text {st }}$ century. The 
object of the article is the analysis of the ways and measures for preservation of Lithuanian statehood. The author referred to the most recent media and provided political analysis of geopolitical and historical context.

Keywords: Security, Lithuania, NATO, EU, armed forces

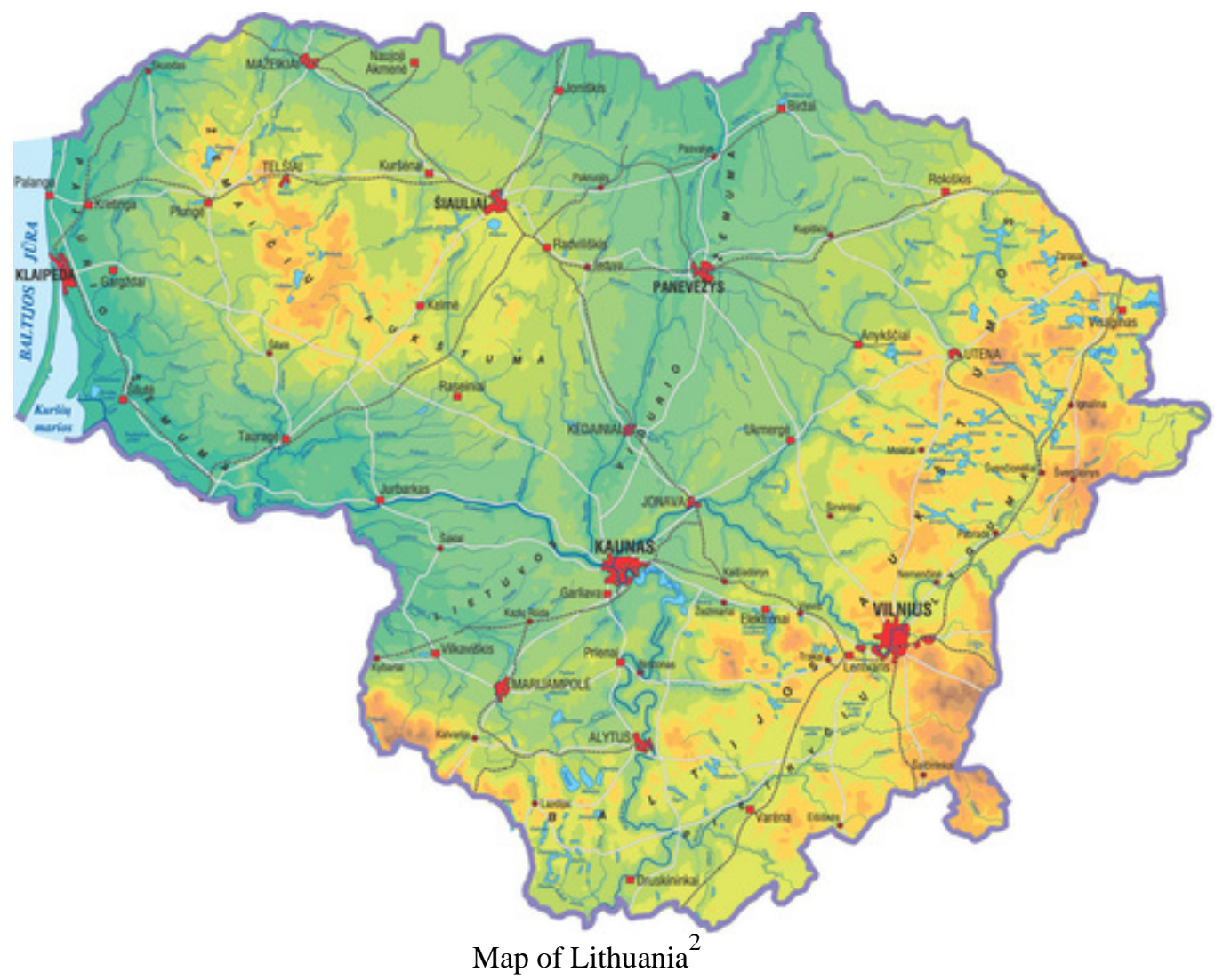

\section{Introduction}

Every state has developed its own concept of security. Security In the classical sense is understood as inviolability of borders, territorial integrity and functioning of constitutional system, i. e. genuine independence. In modern comprehension it encompasses broader spheres: cybernetic, energetic and water security; in the meantime, a new security need has emerged, namely, the safety of radiation sources (with the construction of a new nuclear power plant in Astrav, Belarus, near the south-eastern border). Thus it will test the anti-terrorist capability of the state to timely stop any terrorist attack against people or institutions. This article is based on the

2 Source from Web: http://kazkoksdalykasgeografija.weebly.com/lietuvos382em279lapis.html (accessed 0205 2016) 
classical conception of the word which asserts that security means timely neutralisation of the enemy and preservation of peace and freedom. As Lithuania is in geopolitically insecure region, at the crossroads between the East and the West, by the Baltic Sea, surrounded by big nations, it needs initial long-term strategy in order to secure its survival.

What does the concept of strategy mean? The definition given by the Dictionary of international words says that a strategy is "the theory and practice of the preparation of military forces for war, war planning and fighting “3. Further it might be explained as a prediction of likely events, taking appropriate measures to prevent unfavourable development of events, i. e. to avoid any form of aggression and to diminish the human losses. Despite having the best strategy, possessing a strong army and material basis, the enemy still might launch a treacherous attack; thus it is necessary to create conditions for adequate rebuff to the aggressor in order to defend the territorial integrity of the country. Positive and economically viable internal policy and flexible foreign policy are needed if we are to form a powerful defensive army.

A glance into our history reminds that for Lithuania the adherence to the principle of neutrality often meant the loss of its statehood: the aftermath of the Third Partition of the Polish-Lithuanian Commonwealth in 1795 was the disappearance of sovereign Poland and Lithuania from the map of Europe and the burden of weighty Tsarist yoke for 123 years; the Act of Independence, proclaimed in 1918, had to be defended in fierce battle with enemies attacking from all sides.

Three Baltic States failed to establish a genuine military pact or to strike up a closer economic cooperative ties. The Treaty of Understanding and Cooperation among Lithuania, Estonia and Latvia was signed up in Geneva (Switzerland) on September 12, 1934, establishing the diplomatic alliance, known as the Baltic Entente (Latv. Baltijas Antante, Est. Balti liit). However, it ceased to exist in June 1940, when all three countries were occupied and surrendered without a single shot. ${ }^{4}$ The tacit surrender created favourable conditions for the exile of hundreds of thousands Baltic residents to Siberia. The authorities made a grave mistake having not foreseen the invasion; the silent surrender without armed resistence and lack of preparation for the partisan war was the cause of even greater tragedy.

3 Vyriausioji Enciklopedijų Redakcija. Tarptautinių žodžių žodynas (The Chief Encyclopedic Editions. The Dictionary of International Words). Vilnius. 1985. P. 467.

${ }^{4}$ The Editors of Encyclopædia Britannica. Baltic Entente. Mutual-defense pact [1934], http://www.britannica.com/event/Baltic-Entente (accessed 02/05/2016) 


\section{The Trends of Lithuanian Foreign Policy}

On March 11, 1990 when Lithuania restored its independence, the Government strategically directed its looks towards EU and NATO. Peaceful and friendly foreign policy is embedded in the Constitution of the Lithuanian Republic that was adopted in 1992. The Article 135 reads: "In implementing its foreign policy, the Republic of Lithuania shall follow the universally recognised principles and norms of international law, shall seek to ensure national security and independence, the welfare of its citizens and their basic rights and freedoms, and shall contribute to the creation of the international order based on law and justice. In the Republic of Lithania, war propaganda shall be prohibited." 5

Lithuanian policy towards the Federation of Russia and other former Soviet Republics has been marked by willingness to cooperate, to maintain peaceful and friendly relationship. The programmes of several successive Lithuanian governments reveal their aspiration to enter into an open dialogue with Russia. However, the benevolent aspirations to get along with our mighty neighbour according to the principles of friendship have not contributed to the security of the country.

Only the initial strategic step of Lithuanian foreign policy proved to be effective, i. e. the integration into the EU and NATO. In 1995 the Association Agreement between Lithuania and the EU was signed; it obliged the Government of Lithuania to implement reforms under 33 negotiating chapters to match Lithuanian legislation with European laws, to conform to the legal-democratic standards all spheres of life of the State.

The North Atlantic Treaty Organization (NATO) is an intergovernmental military alliance with a strongly marked defensive character. Countries wishing to join have to meet certain requirements and complete a multi-step process involving poitical dialogue and military integration, implement military reforms to qualify for accession. The connections and interaction of Lithuanian army with the forces of NATO are defined by Lithuanian laws, especially by the Law on the Organisation of the National Defence System and Military Service. Article 3 alinea 2 reads:

2. The National Defence System shall be developed as part of the transatlantic collective defence system. In this regard:

1) the Armed Forces and other institutions within the National Defence System shall be developed in line with NATO standards, and shall be interoperable with NATO structures;

5 Constitution of the Republic of Lithuania. Art. 135 // LR Seimas http://www3.lrs.lt/home/Konstitucija/Constitution.htm (accessed 02/05/2016) 
2) the Lithuanian military and civilian air space surveillance systems shall be developed and integrated into the NATO regional air space control system; and

3) NATO security principles and standards shall be applied in performing security clearances for personnel whose duties involve working with classified material, as well as to ensure physical protection of information, premises, facilities, and other objects and communication systems. ${ }^{6}$

The readiness to cooperate and to contribute to the shared system of global defence is determined by Article 5 of the present Law:

1. The National Defence System will co-operate with NATO structures in planning the defence of Lithuania and in integrating into the transatlantic collective defence system.

2. The Ministry of National Defence shall develop partnerships, multilateral and bilateral international defence programmes with NATO, Western European Union, NATO member states and states seeking NATO membership; and also with other states when such activities correspond with the objective to integrate the Republic of Lithuania into NATO. Institutions of the National Defence System shall co-operate with the above mentioned subjects by:

1) training the Armed Forces in accordance with NATO standards and preparing them and other National Defence System institutions to be interoperable with NATO structures;

2) developing information and communication systems which can be exchanged and secure;

3) in accordance with NATO requirements, standardising defence structures, legal acts regulating defence activities, statutes, terminology, equipment, maps and documentation;

4) training military personnel and defence specialists;

5) obtaining NATO compatible defence equipment; and

6) developing other areas of defence within the National Defence System.

3. In accordance with international co-operation agreements and plans, and in keeping with the conditions for participation in international operations and exercises, the Ministry of National Defence will conduct international military exercises or training in Lithuanian territory, or send units from its armed forces to foreign countries to participate in exercise or training.

\footnotetext{
${ }^{6}$ The Law on the Organisation of the National Defence System and Military Service of the Republic of Lithuania No VIII-723 Vilnius, May 5, 1998 // Seimas Portal // https://www.etar.lt/portal/lt/legalAct/TAR.15C705E93776/ZIQENYsMYW (accessed 02/05/2016)
} 
4. In accordance with international obligations, the Republic of Lithuania, subject to the Seimas approval, shall send its military units to participate in various international military and humanitarian missions in foreign countries. ${ }^{7}$

The North Atlantic Treaty binds its members to search for peaceful means for settlement of any international dispute in such a manner that security and justice are not endangered. Article 2 of the present Treaty reads: The Parties will contribute toward the further development of peaceful and friendly international relations by strengthening their free institutions, by bringing a better understanding of the principles upon which these institutions are founded, and by promoting conditions of stability and wellbeing. They will seek to eliminate conflict in their international economic policies and will encourage economic collaboration between any or all of them. ${ }^{8}$

Estonia met the biggest challenge concerning the relations with Russia: the treaties defining land and sea boundaries were signed in Moscow only on February 18, 2014; the ratification still lies ahead. ${ }^{9}$ The diplomatic insight and boldness of Estonian Government opened the door to the EU and NATO not only to Estonia but to other Baltic countries as well. In July 1997 the European Commission invited Estonia to start accession negotiations, although there was still no border treaty, only technical agreement, signed up on October 25, 2016 by heads of negotiating delegations Kalev Stoicescu (Estonia) and Sergey Lazarev (Russia). The West realised that Estonia had done everything it could and that Russia could not be forced to sign the treaty against its will. And when Estonia was on its way towards EU and NATO, it became clear that Latvia and Lithuania has to be invited as well. ${ }^{10}$

The hopes of the majority of Lihuanian population were fulfilled in 2004 when Lithuania was accepted into the NATO (March 10) and the EU (May 1). ${ }^{11}$ The membership in the EU signified economic, political and cultural convergence with other European States (national citizenship is

${ }^{7}$ Ibid.

8 The North Atlantic Treaty // Washington D.C. 4 April, 1949, http://www.nato.int/cps/en/natolive/official_texts_17120.htm (accessed 02/05/2016)

9 Saatse Strip (boot) Russia-Estonia Border Dispute // Global security 07/11/2016 http://www.globalsecurity.org/military/world/war/ru-et-border.htm (accessed 13/06/2016)

${ }^{10}$ Kadri Liik. The Story of the Negotiations on the Estonian-Russian Border Treaty // Diplomaatia, No 21, June 2005 https:/www.diplomaatia.ee/en/article/the-story-of-thenegotiations-on-the-estonian-russian-border-treaty/ (accessed 13/06/2016)

11 The citizens of the Republic of Lithuania expressed their will in referendum on May 1011 , 2003. Out of $63.37 \%$ of the whole population having the right to vote $91 \%$ voted for membership in EU // Seimas Portal http://www3.lrs.lt/docs3/kad4/w3_viewer.ViewDocp_int_tekst_id=27771\&p_int_tv_id=241 9\&p_org= (accessed 05/04/2016) 
retained but at the same time we share European citizenship). The Parliament of the Republic of Lithuania revealed its foreign policy vision in 2004: to become an active country, visible in the world and influential in the region; to benefit from all the opportunities and resources accorded by the European Union and NATO in order to turn Lithuania, within a reasonably short time period, into a secure, flourishing, competitive and modern economy. ${ }^{12}$ Membership in the EU contributes to the reinforcement of national security and adds some weight to the diplomatic role that Lithuania plays at the regional level. The Lisbon Treaty, effective since December 1, 2009, envisaged the framework for Common Foreign and Security Policy (CFSP) (Art. 28A §3): Member states shall make civilian and military capabilities available to the Union for the implementation of the common security and defence policy, to contribute to the objectives defined by the Council. [...] Member States shall undertake progressively to improve their military capabilities. $^{13}$ (Regrettably, the process of convergence of foreign and defence policy turned out to be rather complicated and the recent years showed that it might be unattainable, at least in the nearest future.) The main tasks of the CFSP are the following:

- $\quad$ Defending core EU interests and independence;

- $\quad$ Strengthening European security;

- $\quad$ Preserving world peace and enhancing international security;

- $\quad$ Promoting international cooperation; consolidating democracy and the rule of law and respect for human rights. ${ }^{14}$

Intergovernmental cooperation is necessary for effective unanimous decisions in the field of foreign policy; decisions on the CFSP are taken unanimously. Member States may abstain. In this case a member shall not be obliged to apply the decision, but shall accept that the decision commits the EU. ${ }^{15}$ A significant stage on the way of creation of a defense union was the non-binding resolution passed by the EU Parliament on November 22, 2016. It envisages establishing EU multinational forces, to allow the bloc to act in

\footnotetext{
12 The Resolution of Seimas of the Republic of Lithuania on Directions in Foreign Policy, May 1, 2004 (official translation // Ministry of Foreign Affairs of the Republic of Lithuania (06/02/2014) https://www.urm.lt/default/lt/uzsienio-politika/savrbiausi-dokumentai/lrseimo-rezoliucija-del-lr-uzsienio-politikos-krypciu (accessed in 05/03/2016)

${ }^{13}$ Treaty of Lisbon Amending the Treaty on European Unio and the Treaty Establishing the European Community (2007/C 306/01) // EUR-Lex http://eurlex.europa.eu/collection/legislative-procedures.html (accessed 13/01/2017)

${ }^{14}$ Common Foreign and Security Policy (CFSP) (updated 21/08/2015) // Ministry of Foreign Affairs of the Republic of Lithuania http://www.urm.lt/index.php?1506345735 (accessed in 05/04/2016)

${ }^{15}$ Ibid.
} 
any situation in which NATO could be unwilling to. ${ }^{16}$ Lithuanian diplomats clearly state that the would-be EU Army should act together with NATO forces under the leadership of the US military headquarters; otherwise, the break between Europe and the USA might lead to serious danger.

The President of the Republic of Lithuania Dalia Grybauskaite, who is responsible for development of the foreign policy as it is indicated in Art. 84 of the Constitution, has highlighted its new strategic direction: "The human being has to become the first priority and the single criterion for evaluation of deeds in every sphere of state policy, the foreign policy included. We may debate on the the forms and tactics of diplomatic activity, but there is one and indisputable strategic direction, namely, the representation of the interests and goals of Lithuanian people as well as our national self-esteem in global arena."17 With that goal Grybauskaite listed the following criteria for her first term in the office: furthering active and businesslike euro-integration and consistent championship of country's interests in the EU; the implementation of the Euro-Atlantic agenda in order to ensure territorial, energetical and technological security making use of the opportunities granted by international organizations; constructive relations with neighbouring countries, based on mutual respect and common benefits. $^{18}$

The Programme of the Fifteenth Government of the Republic of Lithuania (2008 - 2012) posed the following goals: to safeguard the security of the state against external threats possibly constituted by the policy of other countries, support the development of democracy in the geopolitical environment of Lithuania, foster democratic values in the sphere of international relations, create the most favourable external conditions for safe life inside the country. ${ }^{19}$

The successive governments, both leftist and rightist, adhered to this strategic trend of the foreign and defence policy. In the Programme of the Sixteenth Government (Prime Minister Andrius Butkevičius formed central-

${ }^{16}$ Phil Noble. EU Army approved, potentially saddling UK with £420mn annual bill // Russia Today 24/11/2016 https://www.rt.com/uk/367841-eu-army-ratification-brexit/ (accessed 13/01/2017)

17 D.Grybauskaitė: užsienio politikos strateginė kryptis - nacionalinès savigarbos atstovavimas (D.Grybauskaite: the strategic direction of foreign policy - representation of national self-esteem)//ELTA, $2010 \quad 06 \quad$ 08: http://www.ve.lt/naujienos/lietuva/lietuvosnaujienos/d-grybauskaite-uzsienio-politikos-strategija---nacionalines-savigarbos-

atstovavimas/ (accessed 01/05/2016)

${ }^{18}$ Ibid.

${ }^{19}$ The Programme of the Fifteenth Government of the Republic of Lithuania: VII. Foreign Affairs and European policy. Art. 145 // MFA https://www.smm.lt/uploads/documents/veikla/planavimo_dokumentai/15_vyr_programa.pd $\mathrm{f}$ (accessed 01/05/2016) 
leftist coalition government under the leadership of Social-Democratic Party), the continuity is clearly expressed: 524. We shall seek for the partnership with the NATO Member-States and non-NATO countries as it is the best means to ensure the peace and stability in the world. We shall contribute to the constructive and pragmatic relations between the NATO and Russia, between the EU and Russia on mutual lines. We shall continue and intensify the practical cooperation between the Alliance and Russia in such fields as the struggle with drug trafficking, scientific technical collaboration for the sake of peace, transit from Afghanistan, assistance in times of natural disasters and catastrophes. ${ }^{20}$ The need for new approach towards Lithuanian - Russian relations is emphasized: 'Restart' is needed in Lithuanian - Russian relations. We shall ground our cooperation wih Russia on the European values amplifying the mutual trust, paying attention to the future, not to the past; we shall not confine ourselves to prejudiced circumstances, hardly workable conditions which would obstruct mutually beneficial relations between us. The issue of damage done by the Soviet occupation is to be solved negotiating with Russia for mutually acceptable solutions. $^{21}$ The focus of exceptional attention of Lithuania is directed towards the region of Kaliningrad (a.k.a. Konigsberg): Lithuania has a keen interest in brightening up the political dialogue [...], in strengthening of links with the regions of Russian Federation, first of all with Kaliningrad, St Petersburg and Moscow. We shall strive to implement the projects of cooperation across the border with the Region of Kaliningrad, taking into consideration the context of the EU. We shall encourage and promote the development of this region, its openness and cooperation with the EU. Together with the EU, we shall seek to create better possibilities for the residents of border zones (with the extension of border zones) to go to Lithuania and the Region of Kaliningrad without visas. ${ }^{22}$ Promotion of direct ties between the residents of Kaliningrad and Lithuania enables them to explore the natural and cultural riches of both countries, to get acquainted with the economic situation and thus to get rid of stereotyped opinions. No need of comments: Lithuania shows its benevolence to Russian Government and people. Regrettably, the other side does not respond with similar good will. The 'restart' of the relationship has been smeared with the Crimean War and the manoeuvres of the Russian army near the NATO states. The resolution of this government not to forget the issue of damage done by the

20 The Programme of the Sixteenth Government for 2012 - 2016 period: XXI. EU and Foreign Policy. Art. $524 \quad / /$ Seimas Portal http://www3.lrs.lt/pls/inter3/dokpaieska.showdoc_l?p_id=439761 (accessed 25/04/2016)

${ }^{21}$ Ibid. Art. 533

${ }^{22}$ Ibid. Art. 536 
Soviet occupation is praiseworthy, but the determination to strive, to communicate should be shown by both sides, not by Lithuania alone.

\section{The description of the state potential of Lithuania}

A) A state with strong economy will always be more able to purchase or produce more technologically advanced armament. Lithuanian economy ${ }^{23}$, in comparison with other countries, e.g. Finland or Sweden does not have the necessary potential to establish military basis and to arm well at least 30000 soldiers.

The architects of the Lithuanian statehood failed to establish and to preserve middle class layer of the society. Due to the lack of social justice and for economic reasons, there is a large scale emigration: almost a million Lithuanian citizens have left homeland to work or study abroad (at times the percentage of emigration would reach 17\%). According to the data presented by the Department of the Statistics, the number of departures exceeds that of the arrivals. 440,000 people emigrated from Lithuania in the period of 2004 - 2013, while only 85,000 came back. The brighter perspectives of the emigration became visible as well: since 2011 the number of emigrants has decreased, the number of imigrants has increased. In 2014, almost 26,000 former emigrants returned to Lithuania; cf. with 38,500 who left. ${ }^{24 .}$ Despite the positive shift, such quantity of human leakage abroad still makes the situation rather extreme: entire villages disappear and the settlements are deserted. However, recent statistics reveals certain amelioration: foreign investors are setting up their offices in Lithuania and creating hundreds or even thousands workplaces. ${ }^{25}$ Thus the greatest goal of any government is to preserve and to safeguard Lithuania for its citizens and for all people of good will.

B) Lithuania supports the culture and religious life of national communities, their press and education. Thus, there is no reason for national communities' movements or upheavals unless they are instigated by our

${ }^{23}$ Gross national product per capita increased from $\$ 13,020$ in 2011 to $-\$ 15,410$ in 014 according to http://data.worldbank.org/country/lithuania, NY.GNP.PCAP.CD data (accessed 25/04/2016).

24 Oficialios statistikos portalas, (Official portal of statistics) http://osp.stat.gov.lt/web/guest/statistiniu-rodikliu-

analize?portletFormName=visualization\&hash=687e2dfa-2c1b-445b-a (accessed 25/04/2016)

25 Pryšmantas V. Lietuvių darbdavių viliotinis emigrantams: kraukitès lagaminus gyvenimas čia gerejja (Lithuanian employers are luring emigrants - pack your luggage as life here is improving) // Tiesa 2016/04/09, http://www.delfi.lt/news/daily/emigrants/lietuviudarbdaviu-viliotinis-emigrantams-kraukites-lagaminus-gyvenimas-cia-ger (accessed 20/04/2016) 
Eastern neighbour. ${ }^{26}$ Despite ample talking about the need to watch out for the "green little men", they still freely operate at schools and even in governmental institutions. The 2015 report of the evaluation of threats to national security made public by Lithuanian intelligence services pays attention to the signatories of the Independence Act Rolandas Paulauskas and Zigmas Vaišvila and the former vice-minister of Energy Renata Cytacka, at present the member of Vilnius Municipality Council. ${ }^{27}$ Vaišvila is called "one of the most frequently cited Lithuanian politician in the mass-media controlled by the Kremlin" and the consolidator of "non-systematic opposition". ${ }^{28}$ Paulauskas is the leader of the movement "Our ranks"; it was labelled among the organizations which focus most on the spread of proRussian propaganda in Lithuanian internet portals. Paulauskas defines the following words as blackmailing. Cytacka is mentioned as the author of sayings encouraging for establishment of Polish and Russian cultural autonomies in the Baltics. $^{29}$

The same report highlights the exclusive attention of Russian special services and their attempts to exert influence on Russian-speaking young people. The soft power is spread through sport and cultural activities. One of the most popular activities is a kind of military-like competition, pellet-ball games. Visaginas school-children from 2 Russian-speaking gymnasiums and one pro-gymnasium formed a pellet-ball team under threatening title "Shock Combat Batallion". 30 Visaginas school-children participated in the international jamboree of Scouts intended to commemorate the $70^{\text {th }}$ anniversary of the Soviet victory in World War II. $^{31}$ Such facts disclose that there is a favourable background for the spread of Russian influence in the schools of national communities and it may be harmful to the national

${ }^{26}$ In 2016, 116,000 Euros from the state budget were given to partial cultural development projects of national communities. The assessment committee recommended partial financial financing to 114 different projects, including schools, integration expeditions etc.) http://tmde.lrv.lt/lt/naujienos/tautiniu-mazumu-departamentas-prie-lietuvosrespublikos-vyriausybes-skyre-finansavima-tautiniu-mazumu-kulturu-pletote-

skatinantiems-projektams (accessed 05/04/2016)

27 Žvalgybos institucijų akiratyje atsidūręs politikas: nebėra rimtų prorusiškų žmonių Lietuvoje (A politician in the eyeshot of intelligence services: there is no seriously proRussian people in Lithuania) // BNS 30/03/2016, http://www.delfi.lt/news/daily/lithuania/zvalgybos-instituciju-akiratyje-atsidures-politikasnebera-rimtu-prorusisku-zmoniu-lietuvoje.d?id=70837596 (accessed 05/04/2016)

${ }^{28}$ Ibid.

${ }^{29}$ Ibid.

${ }^{30}$ Samoškaite E. VSD: Visagine susiformavo „Smogiamasis mirties batalionas“(The shock death troop was formed in Visaginas) // www.DELFI.lt 30/03/2016, http://www.delfi.lt/news/daily/lithuania/vsd-visagine-susiformavo-smogiamasis-mirtiesbatalionas.d?id=70838032 (accessed 02/05/2016)

${ }^{31}$ Ibid. 
security of Lithuania. Such "upbringing” does not house any gratitude for the upkeep of schools of national communities; it is rather a shelter for the would-be "green little men" who, likely, will emerge when the sign is given. According to Česlovas Iškauskas, a well-known reviewer, how are we to defend from ourselves? Do we have within us at least a centimetre of the "Mannerheim line"? ${ }^{32}$

C) Lithuania is a democratic legal country and its authorities respect human rights and freedoms. The Lithuanian laws comply with international human rights documents. The government maintains a responsible home policy and does not provide any pretext for instability or foreign aggression in the name of defence of Russian-speaking people.

D) Most significant factors for safeguarding the security of the country are the political consciousness of its citizens, readiness to participate in public life and, if the necessity occurs, to defend the Homeland. The Constitution of the Republic of Lithuania reads: The defence of the State of Lithuania against a foreign armed attack shall be the right and duty of each citizen of the Republic of Lithuania. ${ }^{33}$ The defence of Homeland is a constitutional value. The poll carried out at the request by the Baltic Institute of Advanced Technologies (October - December 2014) revealed that the greater part of our citizens comprehend that the security of the country depends on the whole society, and the duty to defend the country belongs not only to the governmental institutions but to all the residents of the country. The percentage of the people who would be ready to defend the country in case of war is rather high, $40 \% .^{34}$ This percentage, however, seems to be meagre if compared to the findings of a similar survey, conducted in Finland in 2011: 76\% were of the opinion that Finns should put up an armed defence in all situations even if the outcome was uncertain; 87\% said they would be ready to take part in various tasks of national defence according to their capabilities and competences. ${ }^{35}$ The Mannerheim line is still vivid in Finns' memory.

The above mentioned factors are especially significant in the context of the defence of Lithuania. As the Lithuanian army is small and poorly armed, on its own, without appropriate backup form the state and the society,

\footnotetext{
${ }^{32}$ Iškauskas Č. Ar yra „Mannerheimo linija“mūsų širdyse? (Is there the "Mannerheim line” in our hearts?) 04/12/2009, http://www.delfi.lt/news/ringas/abroad/ciskauskas-ar-yramannerheimo-linija-musu-sirdyse.d?id=26458327 (accessed 02/05/2016)

33 Constitution of the Republic of Lithuania. Art. 139. LR Seimas http://www3.lrs.lt/home/Konstitucija/Constitution.htm (accessed 02/05/2016)

${ }^{34}$ Lietuviai gintu tèvynę, didžiuojasi lietuvybe, bet tik ne valstybe. // 15MIN 20/01/2015 http://www.15min.lt/naujiena/aktualu/lietuva/lietuviai-gintu-tevyne-didziuojasi-lietuvybebet-tik-ne-valstybe-56-479709 (accessed 20/03/2016)

${ }^{35}$ Interview survey on foreign, security and defense policy of Finland by the Advisory Board of Defense Information. PDF File: Survey_in_english_28_11_2012.pdf
} 
it will be capable to resist against more powerful forces of Russia no longer than two days. The 2015 report of the evaluation of threats to national security points out that the greatest danger for Lithuania arises from Moscow's "imperial ambitions" and the preparation of Russia to rapidly transfer its army: Russia aims to have a significantly shorter military reaction period than NATO. Even now, it would be able to convoke and redislocate its capacities, sufficient to launch the battle activities against the Baltic countries. ${ }^{36}$ Another goal of Russia in case of war is the isolation of the conflict zone. It has already "rehearsed" the situation in the Crimea; now it seeks to establish a complex of military measures in the directions of likely conflict with NATO (the regions of the Baltic Sea, the Black Sea and the Barenz Sea) to maximally aggravate the access of the opposing forces into the region and limit their possibilities to operate there. ${ }^{37}$

The development of events in Syria (on March 14, 2016, the Prezident Vladimir Putin commissioned the Minister of Defence Sergey Shoigu to withdraw Russian armed forces from Syria) caused anxiety among political analysts. They even started to consider the possible dates for Russian offensive against the bloc of NATO, most likely, the Baltic countries. ${ }^{38}$ Now we can only guess what prevented Putin from launching another war or at least from escalating a minor conflict. One more warning came out of the General Richard Shirreff (NATO’s Deputy Supreme Allied Commander in Europe between 2011 and 2014) who said that NATO risks a nuclear war with Russia within a year if it does not increase its defence capabilities in the Baltic States. ${ }^{39}$ He has written a fictional book 2017 War with Russia, and presenting it he assumes that "in a period of tension an attack on the Baltic States ... is entirely plausible" and that the West should act now to avert "potential catastrophe". ${ }^{40}$ In order to preserve freedom, we need armed resistence, cultural, political and civil opposition of the whole people.

${ }^{36}$ Žvalgybos institucijų dèmesys - R. Paulauskui, R. Cytackai, Z. Vaišvilai (The attention of Intelligence services - to R. Paulauskas, R. Cytacka, Z. Vaišvila // Lietuvos žinios 30/03/2016, http://zinios.lt/lzinios/Lietuva/zvalgybos-instituciju-demesys-r-paulauskui-rcytackai-z-vaisvilai/220467 (accessed 12/04/2016)

${ }^{37}$ Ibid.

${ }^{38}$ G. Kasparovas: V. Putinas gali pulti dar šiemet - liepą, rugpjūti arba rugsèji (G. Kasparov: V.Putin can attack this year - in July, August and September )// DELFI 10/03/2016 http://www.delfi.lt/news/daily/lithuania/g-kasparovas-v-putinas-gali-pulti-dar-siemet-lieparugpjuti-arba-rugseji.d?id=70654884 (accessed 12/04/2016).

${ }^{39}$ Charlie Cooper. Nato risks nuclear war with Russia 'within a year', warns senior general. // The Independent 18/05/2016 http://www.independent.co.uk/news/world/europe/nato-risksnuclear-war-with-russia-within-a-year-senior-general-warns-a7035141.html (accessed 12/04/2016).

${ }^{40}$ Ibid. 
Lithuania has learnt the history lesson that firm alliance with blocks of states is a must for such small countries. The NATO block has become the security warrant for the Eastern Europe as it promotes the collective defence, defined in the North Atlantic Treaty, Art. $5 .{ }^{41}$ After the fall of Berlin Wall on November 8, 1989, the Russian Government, even being aware of purely defensive character of the NATO, exacted the promise from the Alliance authorities not to transfer its forces near the border of Russia. (Moscow, on the contrary, builds up huge military bases in the vicinity of NATO member states and even stores nuclear weapons in Kaliningrad Region.) Russia likes establishing rules of the game but it does not want to keep them; it has become obvious through the Ukraine crisis. The Kremlin fails to remain cold-blooded and shows its nerves every time when a new state is invited to accede to the Washington Treaty and become a full member of the Alliance. Even the deputies of Duma (the Russian Parliament) enter this dirty game of threats; they addressed a statement to the parliamentary assemblies of NATO and OSCE countries warning of the possibility of "a new Cold War". ${ }^{42}$ So the NATO is a shield, but is it genuine and reliable armoury or just a wooden toy?

\section{Reflection on the NATO Credibility and Capability to Stop an Agressor}

The attitude of the West to the nations striving for liberty and peace was the betrayal of the ideals; the most eloquent example of such treatment was the outcome of Yalta Conference (1945) - it literally conceded to Stalin almost half of the world, the Eastern Europe (together with the Baltic countries). A more distant impact of Yalta could be felt in Vietnam War (1954 - 1975), as the manifestation of the Cold War between the United States and the Soviet Union and their allies.

Despite seeing the nuclear superiority of the NATO, the Soviet Union created the Warsaw Pact in 1955, officially declaring that it would respect the independence and sovereignty of states and would not interfere in their internal affairs. The context of the Cold War and seemingly soft attitude of the Soviet Union towards its satellites (declaration of Austrian neutrality, concessions to conformist demands of Polish communists, etc.) raised hopes in the Central Europe to break away from the bloc. Hungarian Revolution of 1956 served as an ice-breaker; it was the first Socialist country to declare neutrality and withdraw from the Warsaw Pact. However, this Movement was brutally suppressed by the Kremlin out of fear of possible invasion from

41 The North Atlantic Treaty // Washington D.C. - 4 April 1949, http://www.nato.int/cps/en/natolive/official_texts_17120.htm (accessed 10/04/2016).

42 Gordana Knezevic. Russian Anxiety over Montenegro‘s NATO Accession // RadioFreeEurope, RadioLiberty 26/06/2016 // http://www.rferl.org/a/russia-montenegronato-accession/27821224.html (accessed 10/12/2016) 
the West. The Soviet Union breathed with ease as the international reaction was almost equal to zero. The silence from the American side witnessed that the NATO wanted to avoid military confrontation with the Soviets.

Another Soviet step in testing the determination of the USA to defend democratic values was the Berlin crisis (1958 - 1961). Soviet Premier Nikita Khrushchev demanded that the US relinquish their occupation roles in Berlin and proposed that it become a free city. However, it was clear that the existence of a free Berlin in the enclave of the East Germany is impossible, and the US and the UK refused to satisfy such demands. A major outcome of the Berlin crisis was a final division of spheres of influence between the USA and the SU: the East Europe fell under the dominance of Socialist Camp, while the US and its allies claimed West Europe.

In 1968 Czechoslovakia tested the flexibility of Soviet government with liberalization process aiming to give the Communism 'a human face'. Once again bilateral negotiations led to 'fraternal assistance' against 'antisocial forces', as Jacob Malik, the Soviet ambassador to the UN, put it. ${ }^{43}$ The European NATO allies have responded to the events with far more promise than performance. However, the invasion had demonstrated the unpredictability of Soviet behaviour and it had importantly affected, if not radically changed, the military and security balance in Europe. ${ }^{44}$

The conflict between Moldova and Pridnestrovian Moldavian Republic (Transnistria) remains frozen since 1992. In this case the Russian military contingent (the 14th Army) is the warrant of Transnistria's independence. Moldova, a country with European orientation, engaged in talks with Transnistria in 2013, striving to normalize their ties. Henry Srebrnik, a professor of political science at the University of Prince Edward Island, holds the possibility of renewing the war unlikely, because Putin would actively support Transnistria, while the Moldovans could expect little military aid from the United States and NATO. ${ }^{45}$

Georgia's issue also is worth of analysis. This Caucassian country aspires to become a NATO member. It actively contributes to NATO-led operations in Kosovo and Afghanistan, and the counter-terrorist maritime surveillance operation in the Mediterranean. ${ }^{46}$ In Bucharest Summit of

\footnotetext{
${ }^{43}$ Franck, Thomas M. Nation Against Nation: What Happened in the UN Dream and What the US Can Do About It. Oxford University Press, 1985. ISBN 0195035879

${ }^{44}$ The response of the NATO countries to the invasion of Czechoslovakia. Washington. // CVCE 04/11/1968 http://www.cvce.eu/content/publication/2001/10/15/00661ea1-406149c1-8e9f-f0fd06555082/publishable_en.pdf (accessed 10/12/2016)

${ }^{45}$ Henry Srebrnik. The frozen conflict between Moldova and Transnistria // The Guardian 17/12/2013 http://www.theguardian.pe.ca/opinion/letter-to-the-editor/2013/12/17/thefrozen-conflict-between-moldova-and-3546763.html (accessed 10/12/2016)

46 Topic: Relations with Georgia // NATO http://www.nato.int/cps/en/natohq/topics_38988.htm (accessed 10/12/2016)
} 
NATO in 2008 Georgia was not allowed to join the Membership Action Plan (the USA President George Bush failed to convince his European counterparts to grant this status to it) due to opposition from some countries, especially Germany and France, who feared the decision would anger Russia. Even the promised eventual membership angered Putin: after the 5day War Russia recognized South Ossetia and Abkhazia, as independent countries. ${ }^{47} \mathrm{~A}$ year later a report from EU fact-finding mission determined that the 2008 conflict was caused by Georgia's illegal attack on the South Ossetian capital of Tskhinvali on August 7-8. ${ }^{48}$ It is high time to call the presence of several thousand Russian troops in South Ossetia and Abkhazia an occupation. "Privileged membership" status does not guarantee for Georgia an adequate protection from possible Russian aggression which might arise out of the blue as in March 2014. The world should be on guard against more and more unpredictable Putin.

The West often used to sell their democratic values and humanistic approach for their economic interests and profit. In August 2009, Russian media reported that their country was planning to buy a French BPC-210 Mistral Class amphibious assault ship and negotiating to purchase more ships of the same class. ${ }^{49}$ The deal took up speed; however, in 2015 it was cancelled, and Russia would be refunded the advance payments (€893 mln.). ${ }^{50}$ Despite economic sanctions against Russia, some German companies still cooperate with strategic enterprises of the Russian militaryindustrial complex; e.g. Daimler set up the construction of the plant for cabin co-production with corporation KAMAZ in Naberezhnye Chelny (Tatarstan). Putin desires the Russian army to obtain Western technologies, particularly the latest samples of German military equipment, including centres for military training which had to be built by the German contractor on a turnkey basis. ${ }^{51}$ The Germans' attitude on the collective defence declared in Art. 5 of North Atlantic Treaty is a bit frightening, as only 38 percent of Germans

${ }^{47}$ Ibid.

48 CNN Library. 2008 Georgia Russia Conflict Fast Facts // CNN http://edition.cnn.com/2014/03/13/world/europe/2008-georgia-russia-conflict/～(accessed 10/12/2016)

49 Egypt Buys Mistrals; Kitting Out With KA-52 \& KA-52K. // DFI 21/09/2016 http://www.defenseindustrydaily.com/russia-to-order-french-mistral-lhds-05749/ (accessed 10/12/2016)

${ }^{50}$ Pierre Tran. Mistral Dispute With Russia Settled, France Eyes Exports. // Defense News 09/08/2015 http://www.defensenews.com/story/defense/naval/ships/2015/08/09/mistraldispute-russia-settled-france-eyes-exports/31278439/ (accessed 10/12/2016)

51 Putin's Gamble and the Double Standards of German Business // 31/08/2016 https://tyszecki.blogactiv.eu/2016/08/31/putins-gamble-and-the-double-standards-ofgerman-business/ (accessed 10/12/2016) 
questioned in a Pew poll in the spring of 2015 thought that Germany should use military force to defend a NATO ally that was attacked by Russia. ${ }^{52}$

The economic sanctions to Russia have not brought the desired result only because today the USA and Europe lack genuine political leaders (such as Winston Churchill, Konrad Adenauer, Margharet Thatcher, Ronald Reagan and George Bush). During his visits to Europe and through the talks with European leaders Putin has noticed their laxism and made conclusions that he can settle his affairs with them as he pleases.

When the Crimea was annexed in March 2014 and Donbass taken immediately, the "democrats" of NATO and EU apologised for not having foreseen that and expressed 'their deep concern'. It is easier to show humanism in words, not in deeds: the US ambassador to NATO Douglas Lute announced that there is no chance of NATO expansion in the near future because of fears it could destabilize Russia. ${ }^{53} \mathrm{He}$ confirmed that “there's no way we're going to get consensus any time in the near future on adding ... Georgia or Ukraine".

Ukraine, the country ravaged by military aggression, has been left without an appropriate military assistance, i.e. assault weapons; at present, it alone is anxious to modernize its army and to provide it with powerful military technique. At the face of Russian aggression, the Budapest Memorandums on Security Assurances, 1994 seem to have lost their validity, as none of the parties (the Russian Federation, the UK and the USA) kept their obligations 'to refrain from the threat or use of force against the territorial integrity or political independence of Ukraine; [...] and from economic coercion designed to subordinate to their own interest the exercise by Ukraine'. ${ }^{5}$ Can a country really trust the Alliance when its members breach their promises? Imprudent attitude of Obama pushes America out of arena of the global politics; the newly elected President Donald Trump still has to disclose his political stance on current issues of the world.

Ashton Carter, the head of the Pentagon, expressed his solidarity with the Ukrainians. ${ }^{56}$ The obvious swift in the politics associated with Ukrainian

\footnotetext{
${ }^{52}$ Hans Kundnany. Germany is rekindling its bromance with Russia. // Foreign Policy 07/07/2016 http://foreignpolicy.com/2016/07/07/germany-is-rekindling-its-bromance-withrussia/ (accessed 10/12/2016)

${ }^{53}$ Michael. Holden. No chance of NATO expansion for years, U.S. ambassador says // Reuters, 22/04/2016: http://www.reuters.com/article/us-nato-expansion-idUSKCNOXJ1GM (accessed 15/03/2016)

${ }^{54}$ Ibid.

55 Budapest Memorandums on Security Assurances, 1994 (December 5, 1994) http://www.cfr.org/nonproliferation-arms-control-and-disarmament/budapestmemorandums-security-assurances-1994/p32484 (accessed 12/03/2016)

${ }^{56}$ Remarks by Secretary Carter at Ecole Militaire in Paris, France // U.S Department of Defense, 21/01/2016.
} 
issue might come with the appointment of the new Supreme Allied Commander of the NATO, U.S Army General Curtis Scaparrotti; he says the alliance should possibly arm Ukraine in its struggle against pro-Russian separatists in East Ukraine. ${ }^{57}$

To be honest, European NATO member states heavily rely on the US military resources and financial assistance of the maintenance of the bloc and do not assume responsibility to assign 2\% of their GDP for national defence. A Pew poll disclosed that 34\% of Americans think that Europe has to defend itself by funding the military forces through assignation of $2 \%$ of GDP. ${ }^{58}$

Political attitudes vary both in the US and in Europe; nevertheless, most politicians speak out for suspension of the threat of Russia. Let us remember a theological wisdom: the devil precedes God to make footprins for Him. If Putin can be compared with devil, he did a good job to enable others to chase after him: he aroused the awareness of the Western society for the necessity to arm. The major factor was the incidents involving Russian military aircraft zooming at high speeds past American navy vessels in European waters; they served as the point for criticism to Obama from American Senate and forced him to consolidate the US image in Europe by promises never to leave the European countries alone in the presence of their aggressive neighbour. ${ }^{59}$ Donald Trump, the then "presumptive nominee" of the Republican Party for the presidential elections vowed to shoot down Russian jets approaching U.S. military assets should the Kremlin reject calls to stop. According to him, the U.S. should draw a line in the sand and, if it's

We also have an obligation to protect NATO territory, that's the fundamental commitment of NATO. And sadly, since we saw what happened in Crimea, and elsewhere in Eastern Ukraine, there is, after a quarter century of respite, a new challenge to NATO from the east. Now, that is something that is unfortunate, I wish wasn't the case, but it is. And so, we need to stand strong there, too, and defend allied territory and protect countries and help them protect themselves from the kind of insidious underlining that we saw in Crimea -- that was downright annexation, unheard of since the Second World War. http://www.defense.gov/News/News-Transcripts/Transcript-View/Article/643953/remarksby-secretary-carter-a t-ecole-militaire-in-paris-france (accessed 10/12/2016)

${ }^{57}$ L. Todd Wood. New NATO supreme allied commander: Alliance should arm Ukraine // The Washington Times 04/05/2016 http://www.washingtontimes.com/news/2016/may/4/ltodd-wood-new-nato-supreme-allied-commander-alli/ (accessed 10/12/2016)

58 Katie Simmons, Bruce Stokes, Jacob Poushter. NATO Publics Blame Russia for Ukrainian Crisis, but Reluctant to Provide Military Aid // Pew Research Center 10/06/2015. http://www.pewglobal.org/2015/06/10/nato-publics-blame-russia-for-ukrainian-crisis-butreluctant-to-provide-military-aid/ (accessed 10/12/2016)

59 Andrew Marszal. Obama tells eastern Europe: 'You will never stand alone' // The Telegraph 04/06/2014 http://www.telegraph.co.uk/news/worldnews/europe/ukraine/10874543/Obama-tells-easternEurope-You-will-never-stand-alone.html (accessed 12/03/2016) 
crossed, should shoot down Russian aircraft. ${ }^{60}$ Edward Lucas, the vicepresident of the European politics analysis centre and the senior editor of the British weekly The Economist emphasizes, The NATO in the present form cannot survive long: Europe (with 500 million inhabitants and the GDP of 20 trillion US dollars) cannot endlessly rely on America (with 320 million inhabitants and 17 trillion dollars GDP). The smaller and less wealthy partner of trans-Atlantic alliance not only covers $70 \%$ of its costs, but also assists Europe with modern weapons, heavy vehicles, intelligence service and military knowledge (it also ensures the possibility of nuclear attack if one decided to make use of Alliance security guarantees). ${ }^{61}$

The Russian strategists skilfully make use of national, cultural and political diversity of the EU supporting pro-Russian movements and parties, favourably responding to ultra-rightist nationalist actions and striving to incite anti-American moods. The politicians, however, reflect the opinions of the society; electors vote for those they favour and get such a government which they deserve. NATO should establish an ideological centre for research of public opinion and find means to outweigh the flow of Russian propaganda.

The global geopolitical situation results in decline of AmericanEuropean relations on the governmental degree. Trump inherits a really complicated context and has to put maximum effort to retain the US power and influence it still boasts in the world. Lithuanian government is anxious to know whether the NATO and the USA will confirm their official political determination to provide the Baltic countries with a defensive shield against possible Russian offensive. Will that be determined in advance or decided spontaneously when the threat is embodied? Military prudence requires being ready for any invasion or aggression, but as the winter falls on road servicemen "unprepared", it might happen so when a war is launched. Time is short and evil; it flies and suddenly there is no time for action.

Today the unified EU together with Japan and South Korea helps the USA to remain a global leader; this assistance is mutually beneficial. It enables us to draw the conclusion that this cooperation shall make the NATO a dutiful and effective tool in diminishing Putin's military appetite. The NATO manouvers have been significantly improved both in quantity and in quality; America started to transfer its heavy weapons to Europe; Rapid

${ }^{60}$ Damien Sharkov.Trump Says U.S. Should Shoot Russian Planes if Diplomacy Fails // Newsweek 03/05/2016: http://europe.newsweek.com/trump-says-us-should-shoot-russianplanes-if-putin-calls-fail-454902?rm=eu (accessed 12/ 05/2016)

${ }^{61}$ E. Lukasas: Apie NATO ir Europą - kur D. Trumpas mane pagiria, o aš su juo sutinku (E. Lucas: on NATO and Europe - where D. Trump praises me, and I agree with him) // BNS 14/04/2016 http://lzinios.lt/lzinios/komentarai/apie-nato-ir-europa-kur-d-trumpas-manepagiria-o-as-su-juo-sutinku/221493 (accessed 10/12/2016) 
Reaction Forces (a Very High Readiness Joint Task Force - VJTF, a.k.a. Spearhead Force) have been formed: at the NATO Summit in Warsaw in July 2016, the Alliance formally agreed to deploy for batallions totalling 3,000 to 4,000 troops in the Baltic States and Poland on a rotating basis to reassure Eastern members. ${ }^{62}$ The first military drills "Noble Jump", completed in April 2015, were a part of the learning process that will allow NATO military staff to identify both successes and shortfall as the Alliance continues to refine its high readiness capabilities. ${ }^{63}$ The Exercises disclosed that the Force would be "too vulnerable" against Russia during its deployment phase. Now it's high time to correct and cover the weak spots and to strengthen its powerful points.

\section{Lithuania - a small state with big goals}

1. The initial and further strategy of Lithuania is to support the existence of NATO in all possible legal ways: reinforce the unity of the Alliance; diplomatically criticise the movements in Western Europe supported by the Kremlin; carry out sociological research to find out what part of society supports the development of NATO and what part of it is against the defense of the Baltic States; to lobby politicians who are for the unity of Europe and the NATO with the help of reinforced propaganda; to encourage the officials of NATO and EU to accept Georgia and Ukraine into the Alliance (it will create a good opportunity to “win” Moldova for Europe and pro-NATO: the refusal to grant access to NATO for Georgia prompted Kishinev to follow the neutrality declared in its Constitution; however, Chisinau maintains that it is not an obstacle to cooperation within the framework of the North-Atlantic partnership program and military contribution to Alliance's peacekeeping operations). ${ }^{64}$

2. Lithuania has to support the USA “presence” in the EU. Lithuania has become an active member of the Baltic Assembly, the Baltic Council of Ministers, the Baltic Sea States Council, the Baltic Development Forum, the UN, and UNESCO and adhered to multiple conventions thus contributing to the European security and defence policy, striving for peace, economic growth and social stability in the world. The diplomacy offers broad international opportunities to counterweigh the attempts to drive a wedge, to sow a discord between the USA and EU. (The President of Lithuania Dalia

${ }^{62}$ Spearhead Force. Very High Readiness Joint Task Force (VJTF) // Global Security. http://www.globalsecurity.org/military/world/int/vjtf.htm (accessed 10/12/2016)

${ }^{63}$ Eleven Allies Test NATO 'Spearhead' Alert Procedures on EX NOBLE JUMP // SHAPE Public Affairs Office 09/04/2015 http://www.shape.nato.int/eleven-allies-test-natospearhead-alert-procedures-on-ex-noble-jump (accessed 10/12/2016)

${ }^{64}$ Romania to help Moldova align its army with NATO standards // TASS 23/09/2015 http://tass.com/world/823138 (accessed 10/12/2016) 
Grybauskaite is exceptionally distinguished in the defence of the Ukrainian sovereignty, territorial integrity and the reinforcement of the protection of the East European borders.).

3. The Lithuanian government should seriously consider the INTERMARIUM project; its idea was put forward by Jozef Pilsudski and strongly supported by Andrzej Duda, the President of Poland: "I am considering the idea of creating a partnership bloc stretching from the Baltic to the Black and the Adriatic seas." ${ }^{65}$ Ukraine, Moldova, Romania, Poland, the Baltic States and even Belarus unified as a bloc might serve as a tool to contain the threat from the East. In the given context of unensured survival of the NATO, the idea got support and positive evalution from the Central Intelligence Agency.

4. Another really relevant aspect of security is the necessity of military cooperation with the Scandinavian countries (Denmark and Iceland included). The historical experience of this region in the battles for liberty and preservation of territorial integrity can teach us a lesson and give an opportunity to develop defensive skills and acquire diplomatic wisdom (Norway lost its northern territory and Finland fought for its territorial integrity twice - in 1939 and 1941)

5. "Braliukai" (our Latvian brothers) is a symbol of Baltic unity. Great efforts should be made to establish the Federation of Estonia, Latvia and Lithuania in the nearest future. ${ }^{66}$ Estonia, however, seems to diverge from this an almost century-old project; on the basis of common linguistic roots it tends to approach Finland and looks for similarities with Denmark. The idea of federation with Latvia is a vivid idea on parliamentary level: a group Unity with Latvia has been established in Seimas of the Republic of Lithuania; it deserves wider debate on the public level; the Federation could be an additional factor of security in the Baltic region.

\footnotetext{
${ }^{65}$ T. Urbanskayja, K. Honcharov. Intermarium Alliance - Will the idea become reality? // UNIAN 12/08/2015 http://www.unian.info/politics/1110820-intermarium-alliance-will-theidea-become-reality.html (accessed 10/12/2016)

66 Pukenis R. The Problems in Establishing the Federation of Estonia, Latvia, and Lithuania// Journal of US-China Public Administration, ISSN 1548-6591 August 2012, Vol. 9, No. 8, P. 900-916.
} 


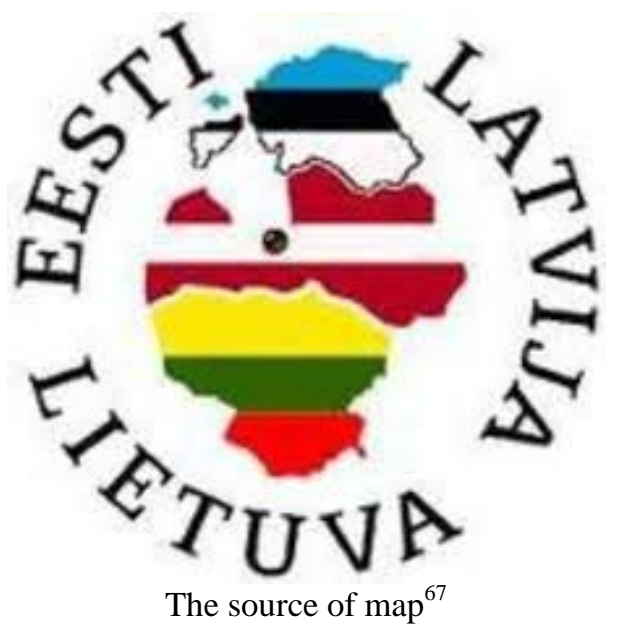

6. The way for the dialogue with Russia should remain open, fostering the economic cooperation based on mutual esteem. Lithuania's contribution to the Eastern partnership program has been appreciated by the NATO headquarters. Due to its favourable geopolitic position at the crossroads between the East and the West, Lithuania has the possibility to stand as a firm column against which may lean the former Soviet countries (Georgia, Moldova, Ukraine, Armenia and Azerbaijan) willing to find understanding and support. Lithuania is strong enough to grant the political asylum for Russian dissidents, to provide them with material support.

There is a wise Roman saying "si vis pacem para bellum" (if you want peace, prepare for war); it emphasizes the role of defensive policy for preserving public security. The Lithuanian National Anthem proclaims the need for the national unity (for the sake of Lithuania let the unity bloom). Alas, the cases of religious or national discrimination still occur and cause tensions; we are forced to forget that every human being has to be treated as the social capital. In order to properly educate the society and prevent it from coming back into the past we have to refute the inculcated opinion that formerly life was better; otherwise the Kremlin's victory in psychological battle would be obvious. The disappointment of citizens with freedom and the failure of governmental social policy to overcome the social inequality would be worse than the Moscow propaganda as it arouses unwillingness to defend such country. The government and the society itself have done too little to stop the emigration from Lithuania. The marked improvement in the activity of the Lithuanian State Security Department work helps to protect the foundations of the statehood. The State Security Department should go

67 The map of Lithuania, Latvia and Estonia Web https://www.google.lt/search?sa=G\&hl=lt\&q=lietuva+latvija+estija+zemelapis\&tbm=isch\& tbs=simg 
on with denouncing collaborators of the country hostile to us and making their names public.

Intensified ties of friendliness and military cooperation with Israel would be a significant factor for the renewal of our security system: Israeli defense model should be at least partly and gradually implemented in Lithuania; it would be prudent to enlarge the army (both by draftees and professional soldiers), to impel women to enter the armed forces and to hold annual training sessions for the reservists. The military service shold become an obligatory prerequisite for anybody wishing to start a political career, as it is in Israel and the US. The finances necessary for the project could be received from Scandinavian countries; by providing the financial assistance to the defense of Lithuania they would secure their own countries. Estonia is another lead for our country: it has developed a well-functioning military education system for secondary schools (in forms $10-12$ ); the theory is taught in regular lessons and practical training exercises are offered to volunteers in paramilitary camps in summer. Lithuania should consider the possibilities to implement similar system at our schools. The most urgent challenge is to assign $2 \%$ of the GDP for defence. It would be a genuine source of financial funding for strengthening the defesnsive border with Kaliningrad Region and Belarus: mining it and entreching anti-tank moats.

Lithuania having had such honourable historical past cannot remain without future. Crises pass, the Lithuanian nation has to "take the ploghw, the book and the lyre" and go along the road of Lithuania. Our destiny determined the necessity to be capable of wielding a weapon. Vytis, the rider depicted on the Coat of Arms, is a symbol of the eternal battle for the Homeland... Generalizing all strategic accents and trends of Lithuanian defence and security, we would like to propose an almost ideal solution to the present geopolitical issues: it would be the Federal Republic of Estonia, Latvia and Lithuania (FRELL) at the crossroad of Europe. The Confederation with Denmark, Iceland, Norway, Sweden and Finland would be even a more perfect outcome, ${ }^{68}$ added to the membership in the EU and NATO. (Articles 43-45 of the Nica Agreement promote the group rapprochement and cooperation of the EU member states.) ${ }^{69}$

\footnotetext{
${ }^{68}$ The Northern Europe goes in this direction; however, these efforts should be intensified. // DELFI 10/04/2015: The ministers of Defense of Northern European countries signed up the Declaration for intensifying the defensive links with the Baltic countries and consolidation of regional security measurers intended to limit the Russian activity in the region. Vienijasi dèl grèsmiu iš Rusijos (Geting united due to Russian threats) // http://www.delfi.lt/news/daily/lithuania/vienijasi-del-gresmiu-isrusijos.d?id=67668830\#ixzz3WvnIQtFU (accessed 04/05/2016)

${ }^{69}$ Trattato di Nizza che modifica il trattato sull'Unione europea, i trattati che istituiscono le comunità europee e alcuni atti connessi (2001/c 80/01), // Gazzetta ufficiale delle Comunita
} 


\section{Post Scriptum}

The bulk of the article was composed in summer in 2016, thus a few remarks are needed to update the geopolitical context that might experience some changes due to the fait accompli, i.e. the presidential elections in the USA. They incited a certain feeling of insecurity among the politicians in the Eastern European countries.

The election of Donald Trump as the President of the USA has emphasized the trends of growing self-isolation or refusal to remain the genuine leaders of the world. Obviously, these processes occur not immediately, but we can perceive clear tendencies that the responsibility of every NATO member-state to put its contribution into the plans of defense is inevitable. Thus, the assertions of the author on the Security Strategy of Lithuania possess essentially logical load of thought: it is not enough to trust the sole alliance with the USA; the future strategy should be created by searching for decent alternatives and developing military cooperation among the Baltic countries and their Scandinavian partners.

\section{References:}

1. Apklausė NATO šalių piliečius: kas gintų sajungininkus nuo rusų? lrytas.lt 2015-06-10, http://pasaulis.lrytas.lt/konfliktai-irsaugumas/apklause-nato-saliu-piliecius-kas-gintu-sajungininkus-nuorusu.htm

2. Bendras nacionalinis produktas vienam gyventojui Lietuvoje, http://data.worldbank.org/country/lithuania.

3. Budapest memorandums security assurances $05 \quad 12 \quad 1994$, http://www.cfr.org/nonproliferation-arms-control-anddisarmament/budapest-memorandums-security-assurances1994/p32484.

4. CNN Library. 2008 Georgia Russia Conflict Fast Facts // CNN http://edition.cnn.com/2014/03/13/world/europe/2008-georgia-russiaconflict/

5. Common Foreign and Security Policy (CFSP) (updated 21/08/2015) // Ministry of Foreign Affairs of the Republic of Lithuania http://www.urm.lt/index.php?1506345735

6. The Constitution of the Republic of Lithuania. Art. 135 // LR Seimas http://www3.lrs.lt/home/Konstitucija/Constitution.htm

7. Cooper C. Nato risks nuclear war with Russia 'within a year', warns senior general. // The Independent 18/05/2016 http://www.independent.co.uk/news/world/europe/nato-risks-nuclearwar-with-russia-within-a-year-senior-general-warns-a7035141.html

europee 10/03/2001 https://www.ecb.europa.eu/ecb/legal/pdf/it_nice.pdf (accessed 04/05/2016) 
8. Egypt Buys Mistrals; Kitting Out With KA-52 \& KA-52K. // DFI 21/09/2016 http://www.defenseindustrydaily.com/russia-to-orderfrench-mistral-lhds-05749/

9. Eleven Allies Test NATO 'Spearhead' Alert Procedures on EX NOBLE JUMP // SHAPE Public Affairs Office 09/04/2015 http://www.shape.nato.int/eleven-allies-test-nato-spearhead-alertprocedures-on-ex-noble-jump

10. Franck, Thomas M. Nation Against Nation: What Happened in the UN Dream and What the US Can Do About It. Oxford University Press, 1985. ISBN 0195035879

11. Grybauskaitė D: užsienio politikos strateginè kryptis - nacionalinès savigarbos atstovavimas// ELTA, $2010 \quad 06 \quad 08$ : http://www.ve.lt/naujienos/lietuva/lietuvos-naujienos/d-grybauskaiteuzsienio-politikos-strategija---nacionalines-savigarbos-atstovavimas/.

12. Gyventojų migracija, http://osp.stat.gov.lt/web/guest/statistiniurodikliu-analize?portletFormName=visualization \&hash=687e2dfa2c1b-445b-a.

13. Holden M. No chance of NATO expansion for years, U.S. ambassador says // Reuters, 22/04/2016: http://www.reuters.com/article/us-nato-expansionidUSKCNOXJ1GM

14. Interview survey on foreign, security and defense policy of Finland by the Advisory Board of Defense Information. PDF File: Survey_in_english_28_11_2012.pdf

15. Kasparovas G., V. Putinas gali pulti dar šiemet - liepą, rugpjūtį arba $\begin{array}{lllll}\text { rugsèj } \quad \mathrm{i} / / & \text { ELTA, } & 2016 & 03 & 10 \text { : }\end{array}$ http://www.delfi.lt/news/daily/lithuania/g-kasparovas-v-putinas-galipulti-dar-siemet-liepa-rugpjuti-arba-rugseji.d?id=70654884.

16. Knezevic G. Russian Anxiety over Montenegro‘s NATO Accession // RadioFreeEurope, RadioLiberty 26/06/2016 // http://www.rferl.org/a/russia-montenegro-natoaccession/27821224.html

17. Kundnany H. Germany is rekindling its bromance with Russia. // Foreign Policy 07/07/2016 http://foreignpolicy.com/2016/07/07/germany-is-rekindling-itsbromance-with-russia/

18. Lietuviai gintų tèvynę, didžiuojasi lietuvybe, bet tik ne valstybe. // $15 \mathrm{MIN}$ 20/01/2015 http://www.15min.lt/naujiena/aktualu/lietuva/lietuviai-gintu-tevynedidziuojasi-lietuvybe-bet-tik-ne-valstybe-56-479709

19. Lietuvos Respublikos krašto apsaugos sistemos organizavimo ir karo tarnybos ịstatymas. 1998 m. gegužès 5 d. Nr. VIII-723Vilnius // Žin., 
1998, Nr. 49-1325, https://www.etar.lt/portal/lt/legalActPrint?actualEditionId=TAIS_246541\&docume ntId=TAR.15C705E93776

20. Liik K. The Story of the Negotiations on the Estonian-Russian Border Treaty // Diplomaatia, No 21, June 2005 https://www.diplomaatia.ee/en/article/the-story-of-the-negotiationson-the-estonian-russian-border-treaty/

21. Lisabonos sutartis, Iš dalies keičianti Europos Sajungos sutartį ir Europos bendrijos steigimo sutarti, 2007, C 306, 01., https://www.ecb.europa.eu/ecb/legal/pdf/lt_lisbon_treaty.pdf

22. LR Seimo rezoliucija dèl LR užsienio politikos krypčių Lietuvai tapus visateise NATO nare ir Europos Sajungos nare, Vilnius. 2004 m,. $\quad$ https://www.urm.lt/default/lt/uzsienio-politika/svarbiausidokumentai/lr-seimo-rezoliucija-del-lr-uzsienio-politikos-krypciu .

23. LR Užsienio Reikalų Ministerija, ES bendra užsienio ir saugumo politika, http://www.urm.lt/index.php?1506345735

24. Lukasas E.: Apie NATO ir Europa - kur D. Trumpas mane pagiria, o aš su juo sutinku (E. Lucas: on NATO and Europe - where D. Trump praises me, and I agree with him) // BNS 14/04/2016 http://zinios.lt//zinios/komentarai/apie-nato-ir-europa-kur-d-trumpasmane-pagiria-o-as-su-juo-sutinku/221493

25. Marszal A. Obama tells eastern Europe: 'You will never stand alone' // The Telegraph 04/06/2014 http://www.telegraph.co.uk/news/worldnews/europe/ukraine/108745 43/Obama-tells-eastern-Europe-You-will-never-stand-alone.html

26. NATO ir Lietuva, http://www.lrs.lt/intl/nato.getFile?doc=5105

27. NATO istatai, http://www.nato.int/cps/en/natolive/official_texts_17120.htm

28. NATO risks nuclear war with Russia 'within a year', warns senior general.18 May 2016, http://www.independent.co.uk/news/world/europe/nato-risks-nuclearwar-with-russia-within-a-year -general-warns-a7035141.html

29. Noble P. EU Army approved, potentially saddling UK with $£ 420 \mathrm{mn}$ annual bill // Russia Today 24/11/2016 https://www.rt.com/uk/367841-eu-army-ratification-brexit/

30. Oficialios statistikos

portalas, http://osp.stat.gov.lt/web/guest/statistiniu-rodikliuanalize?portletFormName=visualization\&hash=687e2dfa-2c1b-445ba

31. Pryšmantas V. Lietuvių darbdavių viliotinis emigrantams: kraukitès lagaminus - gyvenimas čia gerejja// Tiesa, 201604 09: http://www.delfi.lt/news/daily/emigrants/lietuviu-darbdaviu- 
viliotinis-emigrantams-kraukites-lagaminus-gyvenimas-ciagereja.d?id=70805588

32. Pukenis R. The Problems in Establishing the Federation of Estonia, Latvia, and Lithuania// Journal of US-China Public Administration, ISSN 1548-6591 August 2012, Vol. 9, No. 8, P. 900-916.

33. Putin's Gamble and the Double Standards of German Business // 31/08/2016 https://tyszecki.blogactiv.eu/2016/08/31/putins-gambleand-the-double-standards-of-german-business/

34. Remarks by Secretary Carter at Ecole Militaire in Paris, France)// U.S Department of $2016 \quad 01 \quad$ 21: http://www.defense.gov/News/News-Transcripts/TranscriptView/Article/643953/remarks-by-secretary-carter-at-ecole-militairein-paris-france

35. Romania to help Moldova align its army with NATO standards // TASS 23/09/2015 http://tass.com/world/823138

36. Saatse Strip (boot) Russia-Estonia Border Dispute // Global security 07/11/2016 http://www.globalsecurity.org/military/world/war/ru-etborder.htm

37. Sharkov D.Trump Says U.S. Should Shoot Russian Planes if Diplomacy Fails // Newsweek 03/05/2016: http://europe.newsweek.com/trump-says-us-should-shoot-russianplanes-if-putin-calls-fail-454902?rm=eu

38. Simmons K., Stokes B., Poushter J. NATO Publics Blame Russia for Ukrainian Crisis, but Reluctant to Provide Military Aid // Pew Research Center 10/06/2015. http://www.pewglobal.org/2015/06/10/nato-publics-blame-russia-forukrainian-crisis-but-reluctant-to-provide-military-aid/

39. Spearhead Force. Very High Readiness Joint Task Force (VJTF) // Global

Security. http://www.globalsecurity.org/military/world/int/vjtf.htm

40. Srebrnik H. The frozen conflict between Moldova and Transnistria // The Guardian 17/12/2013 http://www.theguardian.pe.ca/opinion/letter-to-theeditor/2013/12/17/the-frozen-conflict-between-moldova-and3546763.html

41. Tautinių mažumų departamentas prie Lietuvos Respublikos Vyriausybès skyrè finansavimą tautinių mažumų kultūrų plètotę skatinantiems projektams, http://tmde.lrv.lt/lt/naujienos/tautiniumazumu-departamentas-prie-lietuvos-respublikos-vyriausybesskyre-finansavima-tautiniu-mazumu-kulturu-pletote-skatinantiemsprojektams 
42. The Editors of Encyclopædia Britannica. Baltic Entente. Mutualdefense pact [1934], http://www.britannica.com/event/Baltic-Entente

43. The Law on the Organisation of the National Defence System and Military Service of the Republic of Lithuania No VIII-723 Vilnius, May 5, 1998, https://www.etar.lt/portal/lt/legalAct/TAR.15C705E93776/ZIQENYsMYW

44. The North Atlantic Treaty. Washington D.C. 0404 1949, http://www.nato.int/cps/en/natolive/official_texts_17120.htm

45. The Programme of the Fifteenth Government of the Republic of Lithuania: VII. Foreign Affairs and European policy. Art. 145 // MFA

https://www.smm.lt/uploads/documents/veikla/planavimo_dokument ai/15_vyr_programa.pdf

46. The Programme of the Sixteenth Government for 2012 - 2016 period: XXI. EU and Foreign Policy. Art. 524 // Seimas Portal http://www3.lrs.lt/pls/inter3/dokpaieska.showdoc_l?p_id=439761

47. The Resolution of Seimas of the Republic of Lithuania on Directions in Foreign Policy, May 1, 2004 (official translation 06/02/2014) // Ministry of Foreign Affairs of the Republic of Lithuania https://www.urm.lt/default/lt/uzsienio-politika/savrbiausidokumentai/lr-seimo-rezoliucija-del-lr-uzsienio-politikos-krypciu

48. The response of the NATO countries to the invasion of Czechoslovakia. Washington. // CVCE 04/11/1968 http:/www.cvce.eu/content/publication/2001/10/15/00661ea1-406149c1-8e9f-f0fd06555082/publishable_en.pdf

49. Topic: Relations with Georgia // NATO http://www.nato.int/cps/en/natohq/topics_38988.htm

50. Tran P. Mistral Dispute With Russia Settled, France Eyes Exports. // Defense News 09/08/2015 http://www.defensenews.com/story/defense/naval/ships/2015/08/09/ mistral-dispute-russia-settled-france-eyes-exports/31278439/

51. Trattato di Nizza che modifica il trattato sull'Unione europea, i trattati che istituiscono le comunità europee e alcuni atti connessi (2001/c 80/01), // Gazzetta ufficiale delle Comunita europee 10/03/2001 https://www.ecb.europa.eu/ecb/legal/pdf/it_nice.pdf

52. Treaty of Lisbon Amending the Treaty on European Unio and the Treaty Establishing the European Community (2007/C 306/01) // EUR-Lex http://eur-lex.europa.eu/collection/legislativeprocedures.html

53. Urbanskayja T., Honcharov K. Intermarium Alliance - Will the idea become reality? // UNIAN 12/08/2015 
http://www.unian.info/politics/1110820-intermarium-alliance-willthe-idea-become-reality.html

54. VSD: Visagine susiformavo „Smogiamasis mirties batalionas“// www.DELFI.lt $2016 \quad 03 \quad$ 30:

http://www.delfi.lt/news/daily/lithuania/vsd-visagine-susiformavosmogiamasis-mirties-batalionas.d?id=70838032

55. Vienijasi dèl grèsmių iš Rusijos//ELTA, www. DELFI.lt, 2015- 0410, http://www.delfi.lt/news/daily/lithuania/vienijasi-del-gresmiu-is rusijos.d?id=67668830\#ixzz3WvnIQtFU

56. Vyriausioji Enciklopedijų Redakcija. Tarptautinių žodžių žodynas. Vilnius.1985. P. 467.

57. Vokietijos atkirtis Rusijai: į̌aldyta svarbi sutartis//BNS ir lrytas.lt inf. 2014-03-20.

58. Wood L. T. New NATO supreme allied commander: Alliance should arm Ukraine // The Washington Times 04/05/2016 http://www.washingtontimes.com/news/2016/may/4/l-todd-woodnew-nato-supreme-allied-commander-alli/

59. Žvalgybos institucijų akiratyje atsidūręs politikas: nebėa rimtų prorusiškų žmonių Lietuvoje// BNS, 201603 30: http://www.delfi.lt/news/daily/lithuania/zvalgybos-institucijuakiratyje-atsidures-politikas-nebera-rimtu-prorusisku-zmoniulietuvoje.d?id=70837596

60. Žvalgybos institucijų dėmesys - R. Paulauskui, R. Cytackai, Z. Vaišvilai// BNS, 201603 30: http://lzinios.lt/lzinios/Lietuva/lietuvoszvalgyba-teigia-jog-vakaru-demesys-rusijos-gresmei-mazes/220467 